\title{
Truth between Semblance and the Real'
}

From the outset the relation between semblants and psychoanalysis was marked by a profound ambiguity. The birth of psychoanalysis, by introducing a new kind of knowledge, that of the unconscious, provoked a tremendous shake up of the moral and social ideals of the epoch, which Lacan in his later teaching qualified precisely as semblants in order to highlight their fictitious character in relation to what really matters to the subject: the real of jouissance and its grappling with it. The precious indications of the function of semblants as a barrier, a defence against the real of jouissance, can be found in Freud's article, “'Civilised' Sexual Morality”, in which he brings to light the antagonism between the semblants of civilisation and the real of the drive, and its devastating repercussions: "Experience teaches us that for most people there is a limit beyond which their constitution cannot comply with the demands of civilisation. All who wish to be more noble-minded than their constitution allows fall victim to neurosis; they would have been more healthy if it could have been possible for them to be less good."

Freud was indeed the first to identify the symptomatic value of the modes of enjoyment as a mark of civilisation's discontent. In fact, according to Freud, sexuality as such can only be conceived as a symptom of civilisation itself. While criticising the ruthlessness of the cultural demand, which involves a repression of drive-jouissance, Freud points out that the growing difficulties of the sexual relation resulting from "the domination of a civilised sexual morality" can lead only to a promotion of 'other modalities' of sexual practice: "It is not difficult to suppose that under the domination of a civilised sexual morality the health

1 This article is a result of the research programme P6-0014 "Conditions and Problems of Contemporary Philosophy" and the research project J6-9392 "The Problem of Objectivity and Fiction in Contemporary Philosophy", which are funded by the Slovenian Research Agency.

2 Sigmund Freud, “'Civilised' Sexual Morality and Modern Nervous Illness” (1908), trans. by. J. Strachey, SE, vol. 9, p. 191.

* Research Centre of the Slovenian Academy of Sciences and Arts, Institute of philosophy, Postgraduate School ZRC SAZU 
and efficiency of single individuals may be liable to impairment and that ultimately this injury to them, caused by the sacrifices imposed on them, may reach such a point that, by this indirect path, the cultural aim in view will be endangered as well.” ${ }_{3}$

Once the social dimension of the symptom has been established, Freud goes on to remind the psychoanalyst that he has the ethical duty not only to disregard prejudices imputable to the sexual morality of his time, i.e. to detach himself from the cultural demands that society imposes on the individual, but also to expose these ideals diffused in society through prohibitions as being nothing but semblants.

Lacan continues in this vein, taking up Freud's idea of the intimate relation between the mode of jouissance and the semblants of the civilisation and the role of psychoanalysis in guiding the subject through the evolution of the semblants of civilisation since the mutation of the Other of civilisation leads to a modification of the form and usages of jouissance: "Psychoanalysis has played a role in the guidance of modern subjectivity, and it would not know how to support it without organising it in accordance with the movement in science that elucidates it."4 Indeed, what place falls to psychoanalysis when the social Other itself strives to inscribe the modes of joussance, that precisely which Freud already considered to be symptoms of civilisation, while assuring them a wholly new legitimacy, and promoting the rules instituting the norms of their integration? ${ }^{5}$ With the decline of the Other there is no instance to prevent "our jouissance going off track", as Lacan puts it. As a consequence, "our mode of jouissance", takes "from now on ... its bearings from the 'surplus-jouissance"”.

To inscribe contemporary modes of jouissance in the current context of the social bond, that is to say in an epoch in which the figure of the Other and its ideals are declining, it is necessary to account for the substitution which has oc-

$3 \quad$ Ibid., p 181.

4 Jacques Lacan, “The Function and Field of Speech and Language in Psychoanalysis”, in Écrits, trans. B. Fink, W.W. Norton \& Company, New York/London 2006, p. 235.

5 Éric Laurent, Jacques-Alain Miller, «L’Autre qui n'existe pas et ses comités d'éthique », $L a$ Cause freudienne (35/1997), pp. 3-20.

6 Jacques Lacan, Television. A Challenge to the Psychoanalytic Establishment, trans. D. Hollier, R. Krauss, and A. Michelson, W.W. Norton, New York, Longon, 1990, p. 32. 
curred at the level of the instance which situates jouissance in the social bond. There are two ways in which jouissance can be situated: by setting up the agent of castration, the second way, on the contrary, involves the investment of the remainder, the stopper/plug of castration, what Lacan termed the surplus-enjoyment, plus-de-jouir. It is precisely at this level that Lacan's remark that "our jouissance... takes its bearings from the "surplus-jouissance" " 7 takes on its full value. What Lacan calls "our jouissance" is exactly the contemporary mode of enjoyment, that is to say jouissance in an epoch in which the Other does not exist, a jouissance which cannot therefore be situated by means of the agent of castration. Joussance today is not situated by means of the ideal, the master signifier, it is not located on the side of the annulment of jouissance, rather, it is situated on the side of the surplus-jouissance as a stopper of castration. It is from such a perspective that human rights are today downgraded to the rights of the surplus-enjoyment.

What is new is that today, instead of being forbidden by the Ideal, jouissance is on the contrary commanded. What has changed is the way in which mass production, through its imperative 'Consume!', proposes jouissance as a semblance for everybody. This phenomenon which could best be described as "haunting the surplus-jouissance" creates the illusion that through the good use of the object a, the surplus-jouissance, we could achieve the complete satisfaction of desire. We can talk of the primacy of the object a over the Ideal which, in turn, is denounced as a mere semblant. The epoch of the inexistent Other is at the same time the epoch of the limitless production of semblants. Thus, it could be argued that the primacy of the surplus-jouissance goes hand in hand with the generalised "semblantification": where there is no instance to keep jouissance in check.

Thus, what were in Freud's time considered to be scandalous, new practices of perversion, are today considered to be an opportunity for the innovation of new semblants in order to inscribe all these various new modes of jouissance. Indeed, it is the new modes of jouissance that present themselves today as a condition for inventing new modes of the social bond, new fictions in Bentham's sense of the word, destined to secure the individual's right to his/her particular mode of jouissance. Hence, the invocations of semblants that organise the social bond and the sexual relation.

7 Ibid. 
Paradoxically enough, psychoanalysis is not without responsibility for this disorientation of the contemporary subject in relation to jouissance since psychoanalysis has itself contributed to the undermining of ideals. Freud, like Bentham, detected behind the ideals of civilisation the modes and the forms of jouissance, in short, the presence of the libido, since, for him, the instance of the superego testifies to a paradoxical satisfaction of the drive disguised as a renouncement of satisfaction.

Yet something has radically changed, insofar as today, psychoanalysis seems to be oddly incapable of effecting a cut, a fracture in the dominant discourse and thereby of undermining contemporary moral and social semblants. On the contrary it seems to be rather a prolongation of this discourse. And it is precisely today, when psychoanalysis seems to be unable to disturb contemporary semblants, to fracture the dominant ideological discourse, that the semblant and its opposite, the real, is the decisive issue. This is why, despite the fact that nothing appears to stop the expansion of the empire of semblants, psychoanalysis has to maintain the real as its compass. But in order to succeed in it, psychoanalysis has to rediscover once more as its proper place the interval between the real and the semblant. Thus, the present interrogation of the semblant stems from the urgency of advancing a new, i.e. 'realist' orientation of psychoanalysis, in an era in which the Other does not exist. Indeed, in an epoch in which the figure of the Other and its ideals are declining, the question of the nature and the use of semblants in psychoanalysis looms higher than ever in the history of psychoanalysis.

The semblant is a term forged by Lacan in the last period of his teaching in order to rework the relation between the symbolic and the real. The introduction of the semblant into psychoanalysis charts a moment of inversion in Lacan's teaching from Lacan's "structuralist phase" to his later teaching centred on the primacy of the real. From the perspective of this shift, the status of the signifier is radically modified: situated within the category of the semblant, the signifier instead of being perceived as a means to secure access to the real, is rather envisaged in terms of a defence against the real. It is this downgrading of the signifier from the structuring principle to the status of a mere semblance that we will be concerned with in this contribution. 
Although the semblant is relevant to numerous contemporary discourses, it is only in psychoanalysis that this term was raised to the level of concept when Lacan, in the course of his elaboration of the psychoanalytic discourse, took up this question to highlight the relation that exists between the signifier and jouissance. And to a certain extent, the semblant is a problem specific to psychoanalysis.

There is indeed a special problem with the semblant in psychoanalysis. Omnipresent, unsettling, yet unresolved, the problem of the semblant comes to the fore at critical moments in the history of psychoanalysis, thereby marking turning points at which the orientation of psychoanalysis is at stake. Thus, Freud himself already tried to circumscribe the problem of the semblant by claiming that "there are no indications of reality in the unconscious, so that one cannot distinguish between truth and fictions cathected with affect". Thus stumbling across what could be termed a primordial deceitfulness at the level of the unconscious, Freud nevertheless refused to consider the distinction between truth and fiction as an operational conceptual opposition in psychoanalysis, thereby indicating that another dimension, that namely what Lacan later names the real of jouissance, is to be taken as compass to orient oneself in the unconscious swarming with semblants. One is almost tempted to say that the price to be paid for the orientation of psychoanalysis towards the real is the downgrading of the concept of truth.

Lacan, likewise, encounters the problem of the semblant at a crucial moment of his teaching, in particular in his seminar on The Ethics of Psychoanalysis, in which he sets out to forge new conceptual tools to treat the real at stake in the analytical experience. More particularly, Lacan broaches the question of semblants at a point in his teaching at which he seems to be turning away from the problematic of truth, that is to say, from that problematic which previously constituted the focal point of psychoanalysis and its specificity in relation to the discourse of science. Indeed, it is under the guise of fiction, a concept borrowed from Bentham, that Lacan first tackles the question of the semblant. The task is to understand, Lacan insists, that what he means by fiction, is not to be confused with its commonly accepted sense: illusion. "Fictitious is not", he claims,

$8 \quad$ Freud's letter to Fliess, dated $21^{\text {st }}$ September 1897, Sigmund Freud Briefe 1873-1939, S. Fischer Verlag, Frankfurt am Main, 1968. 
"in effect, in its essence that which deceives, but is precisely what I call the symbolic". Moreover, the very fact that the fiction is situated by Lacan in the symbolic order involves the displacement of the notion of truth: it is not enough to state with Freud that the opposition between fiction and truth is untenable since truth itself has the structure of fiction. ${ }^{10}$

One might say that, from the outset, the semblant is conceived by Lacan as a paradox of the relation between the symbolic and the real. In this respect, it is interesting to note that although both French terms, 'semblant' (semblance) and 'semblable' (similar), have the same root: the Latin word similes, Lacan's category of semblance is not a new name for the imaginary. On the contrary, semblance, as conceived by Lacan, is intended to designate that which, coming from the symbolic, is directed towards the real. This is precisely what characterises Bentham's fictions. Indeed, as a fact of language, made of nothing but the signifier, Bentham's legal fictions are nonetheless capable of distributing and modifying pleasures and pains, thereby affecting the body. Thus, what held Lacan's attention in reading Bentham's Theory of Fictions was precisely that something which is ultimately an apparatus of language, since fictions owe their existence to language alone, this being properly Bentham's definition of fictions, is capable of inflicting pain or provoking satisfaction that can only be experienced in the body. It appears as if with Bentham's fictions Lacan found at last a missing link, a quilting point between the signifier and jouissance. This is why in Seminar XX, that is to say in a period of his teaching in which the notion of the semblant is well established, he can still remark, in referring expressly to the Benthamite fictions, that the whole purpose in using "the old words" is in their ability to capture jouissance. ${ }^{11}$

There is yet another aspect to the Benthamite fiction that Lacan brought to light, although rather late in the day, in his seminar D'un Autre à l'autre, to be precise. In Lacan's reading, what sets apart Bentham's approach to fictions in his Theory of Fictions from the usual understanding of this term is that Bentham with

9 Jacques Lacan, The Seminar of Jacques Lacan. Book VII: The Ethics of Psychoanalysis, trans. D. Porter, Tavistock/Routledge, London 1992, p. 12.

10 "'Fictitious' means 'fictive' but, as I have already explained to you, in the sense that every truth has the structure of fiction." Ibid.

${ }^{11}$ Jacques Lacan, The Seminar of Jacques Lacan. Book XX: Encore, trans. B. Fink, W.W. Norton \& Company, New York, London, 1998, p. 58. 
remarkable lucidity reveals how all human institutions have as their ultimate finality jouissance. Hence by openly stating that fictions are nothing but an artificial device, "a contrivance", to use Bentham's proper term, designed to provoke either pain or pleasure, Bentham brings into question all human institutions, in so far as they are an apparatus destined to regulate the modes of jouissance by dressing them up in virtues of the useful and the good. ${ }^{12}$ And it is precisely to the extent that the human institutions are recognised as semblants, i.e. as the means and the modes of jouissance, that Bentham's concept of fictions can be seen as a means of denouncing the moral and social ideals of the epoch, of exposing them as being nothing but semblance, a make-believe. In other words, what is scandalous about the Benthamite conception of fictions is precisely this hardly concealed cynicism reminding us of the primacy of jouissance. Indeed, unlike the rest of human institutions, in order to be operational Bentham's fictions can do without the masquerade, more precisely, without the belief in moral or cultural ideals. From the perspective of Bentham's cynicism, a crucial feature of semblants is thus brought to light: the constitutive role of belief. Broadly speaking, the semblant is present in any form of belief. So if semblants are destined to cover up the economy of jouissance, they can only succeed in their task if we believe in them, that is to say, if we take their make-believe at face value. With Bentham's fictions, on the contrary, we are dealing with a semblant which openly declares that it is nothing but a make-believe. Bentham's fiction is then a paradox of semblance, a paradox of lying truly.

From the moment fictions are conceived by Lacan as the very means with which to modify the subject's relation to jouissance, his whole elaboration of the analytical practice changes. The lesson to be dawn from Bentham's cynical use of fictions is the following: If the fiction is in itself, strictly speaking, a fallacy, a make-believe, a semblance, yet a semblance which presents itself as semblance, hence, a reflexive semblance, this means that it is possible to use fictions in order to attain the real without believing in them. As such, the fiction is capable not only of touching the real but also of denouncing, exposing semblants disguised as moral virtues. And it is precisely in this double capacity of a semblant hostile to semblants, if we may put it so, which is nevertheless able to attain the real, that the question of the semblants is posed to Lacan first of all as the question of how to put semblants to good use. Indeed, what use is to be made of semblants

${ }_{12}$ Jacques Lacan, Le séminaire, livre XVI, D’un Autre à l'autre, Seuil, Paris 2006, p. 190. 
in psychoanalysis is of paramount importance to Lacan once it is admitted that fictions are in themselves indifferent to either "good use" or "abuse". Actually, it is for that very reason that Bentham sets out to replace the existing unjust legal fictions, which profit the shrewd and powerful, with a system of fictions which would assure the maximising of pleasure and minimising of pain for the society as a whole. Yet the question of know-how with fictions, as a symbolic apparatus destined to intervene in the real of the body, demands a radical reorientation of psychoanalysis in which the role of the structuring principle is attributed to the opposition between the real and semblants.

We can see now how Lacan's redeployment of Bentham's concept of fiction made it possible for the real at issue in psychoanalysis, the real of jouissance, to emerge as such. In view of this shift in Lacan's teaching which defines psychoanalysis not in its relation to truth but in its relation to the real, a shift which coincides with his elaboration of the notion of the fiction, it may appear odd that the notion of the semblant did not find what might be called its proper place until the seventies, as testified by the title of the seminar which was intended to specifically address the issue of the semblant: D'un discours qui ne serait pas $d u$ semblant (A Discourse Which Would Not Be of Semblant).

There is one further consideration about the Lacanian concept of the semblant that should be mentioned. The fact that this notion, which could truly serve us as a key to Lacan's later teaching, did not receive the attention it deserves until recently, can be attributed in large part to the circumstance that the seminar in which the problem of the semblant is discussed, A Discourse Which Would Not Be of Semblant, occupies a transitional place between Seminar XVII, On the Other Side of Psychoanalysis, and Seminar XX, Encore. Unlike the seminar of the semblant, these two landmark seminars which discuss two issues of general interest, power and sexual difference, have come to take up a prominent place in contemporary debate across an impressive range of disciplines. Consequently, the semblant as a key concept which marks a momentous shift in Lacan's teaching from the symbolic to the real as a focal point of psychoanalysis has passed largely unnoticed. 
As has already been pointed out, ${ }^{13}$ at the beginning Lacan used both terms, 'semblant' and 'fiction', practically as synonyms. To account for this equivalence of both terms we propose the following hypothesis: it is because Lacan grasps the specificity of the function of the semblant, regardless of the term used in the knot it effects between the symbolic and the real, that 'semblant' and 'fiction' are in Lacan's view exchangeable. Nevertheless, in the seventies, the term 'fiction' practically disappears from Lacan's vocabulary. One reason why he gives up the notion of the fiction in the end lies no doubt in the fact that the concept of the fiction is too restrictive: whereas the fiction is strictly speaking language dependent, the semblant, insofar as it exists in nature, does not owe its existence to language. Actually, all the examples used by Lacan to illustrate the notion of the semblant in his seminar D'un discours qui ne serait pas $d u$ semblant, are exactly non-discursive semblants, semblants in nature, such as rainbow, thunder, and meteors. ${ }^{14}$ This very fact indicates that the concept of the semblant, while partly overlapping with that of the fiction, is nonetheless irreducible to it. Here, one finds a shift in Lacan's theory of the semblant and a break with the Benthamite paradigm. While one of our aims is to briefly outline the development of the Lacanain concept of the semblant, we also wish to draw attention to some difficulties that highlight the ambiguous status that the semblant has in psychoanalysis. Indeed, in an epoch in which the figure of the Other and its ideals are declining, this question of the nature and the use of semblants in psychoanalysis looms higher than ever in the history of psychoanalysis. But to what function exactly, one might wish to ask, does this notion of the semblant respond in the psychoanalytic discourse?

It should be noted, however, that 'semblant', as a term, may well have been a late entry into Lacan's vocabulary, that which appears to be essential in the question of the semblant: the articulation between two radically heterogeneous if not antinomic registers, the symbolic and the real, is, on the contrary, a persistent problem throughout his teaching. As a matter of fact, Lacan never stopped inventing new terms destined to hold together that which does not hold together. Jouissance and the signifier. In the course of his teaching, he explored the

13 The genesis of Lacan's notion of the semblant has been outlined by P.-G. Gueguen in a session of the 17 December 1997 during J.-A. Miller's course "Le partenaire-symptôme," 1997-98.

14 Jacques Lacan, Le séminaire, livre XVIII : D’un discours qui ne serait pas du semblant, Seuil, Paris 2006. 
different ways of capturing jouissance via the signifier. Starting with the phallus, also designated as the signifier of jouissance, Lacan inaugurates an extraordinary series of terms that replace one another in this function of the anchoring point, the nodal linkage between the symbolic and the real: the-Name-of-theFather, the master signifier and finally the object a. Each of this terms will come, in the course of Lacan's teaching, to fulfil the quilting function, provided that it responds to the structurally necessary demand of building a bridge between two antinomic instances: the signifier and jouissance. On the other hand, the very fact that Lacan invented a new category, that of the semblant, and introduced it into psychoanalysis, along with his major categories of the real, the symbolic and the imaginary, testifies to the fact all these various attempts at solving the problem of the disharmonic relation between the real and the symbolic, in the final analysis, the relation of the subject of the signifier and the real of jouissance, proved to be unsatisfactory.

Thus, considered in retrospect, it is perhaps no accident that Lacan raised the thorny question of the semblant in the wake of his seminar on The Other Side of Psychoanalysis. The elaboration of the four discourses is for Lacan an opportunity to revisit his initial departure point: the disjunction between the signifier and jouissance, in such a way that behind the overt antithesis between signifier and jouissance, their clandestine solidarity is revealed.

In this seminar Lacan namely argues that discourse is a structure which is able to subsist due to certain fundamental relations that would not be able to be maintained without language. ${ }^{15}$ The distinction between discourse and speech, the latter being always more or less occasional, is crucial here insofar as it translates, at the level of language, the distinction between variable and invariable. Indeed, by opposing discourse and speech, Lacan clearly aims at situating discourse on the side of that which remains invariable, which remains the same, untouched by what is meant or said of it. One is almost tempted to say that discourse, to the extent that it is defined as a structure, is an instance of the real in language. Indeed, Lacan's theory of the four discourses is grounded in an idea which traverses the whole of his teaching, namely that for psychoanalysis, just like for science, there should be some symbolic in the real. If psychoanalytic

15 Jacques Lacan, The Seminar of Jacques Lacan, book XVII: The Other Side of Psychoanalysis, trans. R. Grigg, W.W. Norton \& Company, New York/London 2007, p. 13. 
theory has for its object the unconscious, then it has as its charge the task of demonstrating that this peculiar kind of knowledge which cannot be assigned to an 'I', keeps returning to the same place, i.e. is situated in the real. Clearly, mathematical writing provides a model in this regard insofar as Lacan indicates that there is discourse in the real, that there are formulae, which the subject obeys without knowing it. It is from such a perspective that Lacan states that discourse should be taken as a social bond, and sets out to articulate the four distinct discourses in order to show what distinguishes psychoanalysis qua social bond from other discourses.

The structure of discourse itself is determined on the basis of the dominant position of the master signifier, $\mathrm{S}_{1}$, in the master's discourse since the master discourse is that discourse from which all the other discourses are derived. The master's discourse is, in effect, constructed as an elementary matrix of language that is the condition for the unconscious: one signifier, $\mathrm{S}_{1}$, represents the subject (placed under the bar) for another signifier, the product of this structure is its waste product, that which drops out: the objet $a$, an incalculable, inassimilable remainder of jouissance termed by Lacan the plus-de-jouir, surplus enjoyment which the system cannot absorb. By occupying the place of the agent in a given discourse, any of these four terms, $\$, \mathrm{~S}_{1}, \mathrm{~S}_{2}$, and $a$, reveals at the same time its true character of the semblant. What Lacan called the structure of discourse gives us already a signifying structure that includes as one of its elements something which is not a signifier, a disparate element: the object a, a paradoxical symbol which, without being a signifier, obeys the laws of the signifier, interrelating with other signifiers: $\mathrm{S}_{1}$, the master signifier, $\$$, the divided subject, $\mathrm{S}_{2}$, knowledge. In the analyst's discourse the psychoanalyst is positioned precisely in the place of the object a as the surplus-jouissance. In the four discourses, Lacan reverses the formula of fantasy, the barred subject and the object a, in order to inscribe the object a, in the analyst's discourse, in the place of agent, thus showing that the object a functions there as a signifier.

Psychoanalysis is based on the assumption that the treatment of the real, more specifically, the real of jouissance, by the signifier is only possible within the framework of discourse. Not just any discourse, of course, but that which, like Freud's "maintains itself as close as possible to what refers to jouissance". ${ }^{16}$ In

$16 \quad$ Ibid., p. 71. 
other words, the pivotal point in the analyst's discourse is the relation between the signifier and jouissance. It is for that reason that, according to Lacan, the discourse that brings the other three to light is the analyst's discourse. Indeed, from the perspective of the relation between the signifier and jouissance, the task of the analyst's discourse is to expose the surreptitious alliance between the signifier and jouissance as constitutive of any social bond. Lacan's definition of discourse as a social bond can thus be understood also in the sense that it is a bond between the signifier and jouissance. From such a perspective, the analytic discourse can then be seen as a specific apparatus destined to uncover how instead of being a defence against jouissance, the signifier appears to be the condition of its possibility, moreover, an apparatus that produces jouissance.

Before the signifier could be situated in the order of the semblant, it was therefore necessary for Lacan to expose the duplicity of the signifier: the signifier which was initially defined by Lacan through the exclusion of jouissance, a barrier against jouissance, is revealed to be an apparatus of jouissance. ${ }^{17}$ Indeed there is a dialectic of the lack and the supplement at work in the relation between the signifier and jouissance. On one hand, the signifier involves the loss of jouissance, its annulment. On the other, however, this very loss, as effect of the signifier responds to the supplement of jouissance termed by Lacan as the object $a$, the surplus-jouissance. Thus it could be said that the loss of jouissance produced through the signifier is the condition of the possibility of repetition, encore, once more, again and again, and it is precisely through this repetition that a surplus is produced. Hence, the lesson to be drawn from the seminar On the Other Side of Psychoanalysis, is that the loss of jouissance and the surplus-jouissance, the plus-de-jouir, are both produced through the functioning of the signifier. Indeed, what is seen from one perspective as a loss of jouissance is seen from another as the production of a surplus. The signifying articulation thus appears to be an apparatus in which a loss, the minus, is converted into a gain, the plus. It is from such a perspective according to which the loss of jouissance produced through the functioning of the signifier is converted into the surplus-jouissance, the plus-de-jouir, that it could be argued that Seminar XVII, in a sense, anticipates the seminar D'un discourse qui ne serait pas du semblant.

${ }_{17}$ See Jacques-Alain Miller, “Equivalence Between the Other and the Symptom”, Psychoanalytical Notebooks (12/2004), p. 12. 
The very fact that Lacan invented this category after the deployment of the four discourses as the foundation of any possible social bond signals that a necessary step in the genesis of the Lacanian concept of the semblant was precisely the uncovering of the solidarity between the signifier and jouissance, a solidarity in which the social bond as such is grounded. Thus, in following the construction of the discourses we can see that the social bond as such concerns not only the signifier but also jouissance.

We will argue that this inversion of perspective is inscribed in the very logic of permutation which enables the passage from one discourse to another. What is crucial in this respect is the relationship between the master discourse and the analyst's discourse, since, as indicated by the title of the seminar, the master's discourse is the reversal or the other side of the analytic discourse. While the master's discourse "has only one counterpoint, the analytic discourse" ${ }^{18}$, as Lacan states, their relationship is rather intricate. On the one hand, the master's discourse is defined as the cause of the analyst's discourse, since, as Lacan claims, "analytic practice is, properly speaking, initiated by this master's discourse" ${ }^{19}$. On the other hand however it is remarkable, as Lacan himself concedes, that "it is fairly curious that what [the analyst's discourse] produces is nothing other than the master's discourse, since it is $S_{1}$ which comes to occupy the place of production", but in saying that Lacan seems to be opening up the possibility that "perhaps it's from the analyst's discourse that there can emerge another style of master signifier." ${ }^{20}$ It could then be said that, in a general way, the four discourses are interrelated insofar as the term produced as a waste by one discourse migrates to the place of the agent in another discourse.

In the analyst's discourse, the place in the upper left-hand corner of Lacan's quadripartite structure of the discourse qua social link, the place of the agent, is attributed to the psychoanalyst in so far as $\mathrm{s} /$ he assumes the function of the objet a, i.e. the place of the plus-de-jouir, surplus jouissance. This particular property of the analyst's discourse singles out the place of agent as equivalent to the semblant. Indeed, semblant is the name by which Lacan designates this place of the agent or 'dominant' place, as he calls it, in all four discourses. For Lacan

\footnotetext{
18 Lacan, The Seminar Jacques Lacan, book XVII: The Other Side of Psychoanalysis, p. 100.

19 Ibid., p. 152.

$20 \quad$ Ibid., p. 176.
} 
this brings the question of semblance, that is to say, the question of the instance occupying the place of agent, the dominant place. We will address this question by following Lacan's indications in his seminar entitled Encore: "Before the semblance, on which, in effect, everything is based and springs back in fantasy, a strict distinction must be made between the imaginary and the real. It must not be thought that we ourselves in any way serve as a basis for the semblance. We are not even semblance. We are, on occasion, that which can occupy that place, and allow what to reign there? Object a." ${ }^{21}$

In this quotation Lacan revisits his own theory of the four discourses, questioning, in particular, that there is a link between semblance and the place that the psychoanalyst occupies in the matheme of the analyst's discourse. More precisely, he notes the fact that in this construction of the four discourses, the semblant is already slipping in. It is precisely from this perspective, according to which, as speaking beings, we are subjects, condemned even, to semblance, that Lacan revisits his theory of the four discourses, in showing that the analyst, by positioning himself or herself as objet $a$ in the place of the agent, the dominant place, occupies the place of semblance.

While, strictly speaking, the analyst's discourse can not be considered to be a discourse that is not of the semblant, its privilege consists nevertheless in its ability to perceive the semblant for what it is: precisely a semblant. The very fact that in the analyst's discourse the analyst is situated in the place of the agent, permits it, by using the very mechanism of the production of the social bond, i.e. through this peculiar mode of mimicking the structure of the social bond which is sustained only by virtue of the make-believe situated in the place of the agent, to reveal the semblant itself. By exposing the semblant as a deceitful fiction, the analyst's discourse is for that reason able to subvert the make-believe of the social bond that is present in the other three discourses, the master's, the hysteric's and the university discourse.

It is from such a perspective that Lacan himself underlined the fictional foundation of psychoanalysis: paradoxically one should pay respect to the psychoanal-

${ }_{21}$ Jacques Lacan, The Seminar of Jaques Lacan, Book XX: Encore, or On Feminine Sexuality, The Limits of Love and Knowledge, trans. B. Fink, W.W. Norton \& Company, New York/London, 1998, p. 95. 
ysis of our time, he said, in so far as it "is a discipline which produces itself only through the semblant. The latter in it is denuded to the point that it unsettles the semblants which support religion, magic, piety, all that which conceals the economy of jouissance". ${ }^{22}$ This remark assumes its full value on the condition that one treats the semblant through the psychoanalytic discourse. ${ }^{23}$

The very promotion of the social bond implies for Lacan the radicalisation of the relation between the real and the semblant. Indeed the point of departure of the Lacanian concept of discourse is the steady erosion of the Other and its ideals. If the question of the real was encountered so acutely by Lacan in his Seminar XVII, it is because, from the perspective of the inexistence of the Other, from a perspective in which the Other with its ideals is downgraded to the status of the semblant, the real itself seems to vacillate. Indeed, what remains of the real if the Other is not real, if it has the structure of a fiction? Actually, the very idea of the four discourses, four mathemes, four discursive structures, is inspired by the knowledge in the real that the discourse of science in transcribes in mathematical formulae. In a way, the four discourses are Lacan's desperate attempt at restoring the Other - under the guise of the discourse structure. Just as for science there is a knowledge in the real, there are discourse structures in the real for psychoanalysis. Lacan's concept of discourse could then be considered to be a new edition of the Other as a structure in the real.

Of course, the Other in this new edition is not to be confused with the master signifier. The Other may well be concentrated in the place of the master signifier, but it could also be situated in the place of knowledge, that of product, in short, it would be more appropriate to situate knowledge at the level of the discourse as such. It is the structure of the discourse which can now be identified with the Other. Only in this sense can Lacan maintain in his seminar Encore that "the notion of discourse should be taken as a social link, founded on language." ${ }^{24}$ In other word, the Other, from the perspective of the four discourses, is not an instance that can be isolated, rather it is the very knot of all four instances. It is an attempt at maintaining the function of the quilting point without it being

${ }^{22}$ Jacques Lacan, « Discours à l'École Freudienne de Paris » in Autres écrits, Seuil, Paris 2001, pp. $280-281$.

23 Jacques Lacan, « L' Étourdit » in Autres écrits, pp. 449-495.

24 Lacan, The Seminar of Jacques Lacan, Book XX: Encore, p. 17. 
assigned to a particular instance. In this sense, the four discourses as a figure of the Other already announce the Borromean knot insofar as the Borromean knot is a solution proposed by Lacan to show how three heterogeneous orders the imaginary order of meaning, the symbolic order of knowledge and the real order of jouissance, hold together.

The four discourses can then be perceived as a desperate attempt to elevate psychoanalysis to the level of science. The idea according to which the structures of discourse are inscribed in the real is an ingenious invention which permits psychoanalysis to determine the specificity of the real that is at the core of its experience, and at the same time to avoid the snares of contemporary relativism according to which everything is semblant. The construction of the four discourses is an operation comparable to Galileo's and Newton's founding gesture of science, a gesture which consists in the strict separation of the real from the semblant. In other words, the four discourses are Lacan's attempt at circumscribing the place of the real in psychoanalysis while limiting the imperialism of semblants. And just like the knowledge in science that not only "reads", determines, deciphers the knowledge in the real by writing it down in mathematical formulae in order to transform it, psychoanalysis also presumes to be able to determine the real it deals with and to find a way to transform it.

The opposition of the real and semblance is therefore a crucial step in the development of Lacan's teaching: it is a radicalisation of the opposition introduced in his seminar on The Ethics of Psychoanalysis between the real on one hand and the symbolic and the imaginary on the other, so that it could be said that, from the point of view of the real, the symbolic and the imaginary appear to be equivalent. Yet this opposition between the real and the semblant became a structuring opposition only once Lacan accomplished the construction of the four discourses.

Contrary to what one might believe - guided solely by the title which is rather equivocal since it evokes the possibility of a discourse that would not be a semblant - the central issue in the seminar D'un discours qui ne serait pas du semblant is not the elaboration of a discourse that would not be a semblant, with the surreptitious implication that psychoanalysis might be, together with science, this discourse. On the contrary, from the beginning of this seminar, Lacan states in no uncertain terms that insofar as the signifier itself is the sem- 
blant, all that belongs to the discursive order necessarily falls under the rubric of the semblant. ${ }^{25}$ In other words, the semblant is a category inherent to the discourse as such.

Having established that in discourse the semblant is irreducible and that, consequently, there is no discourse that is not of semblant, the discourse of psychoanalysis being no exception, Lacan moves on to broach the question which is udoubtedly the crucial issue around which the major part of Seminar XVIII revolves, namely: once the constitutive lack, absence, the lack of the discourse of the real is admitted, how the problem of holding together the symbolic and the real, two heterogeneous registers, while maintaining their irreducible heterogeneity, be solved.

This constitutive lack of the discourse of the real is what leads Lacan to deploy a new category and to pose the question of knowing what is the real from a new perspective. If the question of the real poses itself to Lacan so persistently in the final period of his teaching, this is precisely because the real proper to the analytic experience is now considered to be resisting signifierisation, i.e. its conversion into the symbolic. In view of such a radicalised conception of the real, both, the imaginary and the symbolic, appear as a mere make-believe. This question of the real as being both, outside the imaginary and the symbolic, prompts Lacan to entertain the hope of a psychoanalysis which would not be founded on semblant. By naming his seminar consecrated to the question of the semblant "Of a Discourse Which Would Not Be of Semblant", Lacan seems to be nourishing, encouraging the mere hope of the possible elaboration of a discourse that would not be reducible to a mere semblant, like the rest of them, but would rather be a discourse of the real. To the extent that since the symbolic is now seen to be downgraded to the order of semblant, this seminar which evokes the possibility of a discourse which would take its departure point from the real thus signifies a turning point, a pivoting of perspectives in Lacan's teaching insofar as, at the outset, Lacan proposed to ground psychoanalysis as a discourse on the symbolic. It is at this point in Lacan's later teaching, at which psychoanalysis is ordered by the relations of the semblant and the real, that a large part of Lacan's theorisation which had been deployed in the register of the symbolic, appears to be reduced to the mere status of semblance: sicut palea.

25 Lacan, Le séminaire, livre XVIII: D'un discours qui ne serait pas du semblant, p. 14. 
In a sense it is only from the perspective of the semblant that one can realise that what creates an impasse here is that, actually, the cleavage between the signifier and jouissance was surreptitiously created by Lacan's proper definition of the subject. Conceived in terms of the signifier - the subject is what one signifier represents for another signifier - the Lacanian subject is essentially empty, dead, devoid of "enjoying substance", severed from jouissance. The outcome of this irreducible disjunction between the subject of the signifier and the real of jouissance entails the coupling of the empty subject with the remainder of jouissance: the object $a$. With the object $a$ as an answer to the lack of signifier, Lacan inscribed in what he called the four discourses a real that is within the reach of the subject of the signifier.

In Seminar XVIII Lacan started to bring into question the union of the symbolic and the real, and by so doing he proposed at the same to reconsider psychoanalysis and its practice from a different perspective: that of the disjunction of the symbolic and the real, from a rapport of the exteriority between the two, ultimately, from their non-rapport. From this perspective of non-rapport Lacan's seminar D'un discourse qui ne serait pas du semblant marks a crucial turning point at which the future orientation of psychoanalysis is at stake. Hence, despite Lacan's usual style of self-assurance and confidence, this seminar is nevertheless a seminar of hesitation as regards the possible ways of overcoming the impasse implied in the non-rapport between the signifier and jouissance. In fact, the question of a new departure point involving a radical inversion of perspectives plays across the whole surface of this seminar. The deployment of the notion of the semblant throughout this seminar allows it to gather its consistency, while at the same time providing the points of vacillation and resistance necessary for it to establish the themes that he pursues in the final period of his teaching. Lacan tentatively proposes various solutions to the problem that the articulation of registers which are absolutely heterogeneous poses, while avoiding at the same time the previously privileged device: the quilting point.

Thus, by taking up the question of the semblant in its relation to the real, Lacan's Seminar XVIII is therefore, from the beginning, quite radically a question of defining a new type of articulation separating jouissance and the signifying articulation. In the context of Lacan's project thus outlined, the theory of semblants, insofar as it breaks with his previous assertion of the primacy of the symbolic, can be perceived as a "vanishing mediator", a necessary step on the path to the 
final solution: the Borromean knot, this being exactly the perspective in which all three registers, the symbolic, the imaginary and the real are considered to be independent and autonomous registers, absolutely equivalent at the level of the knot. Lacan's project thus becomes that of separating the three orders, while at the same time exploring many different ways in which it is possible to produce a new kind of knotting at the level of jouissance. The issue here is of course that of jouissance and the different ways in which it is elaborated at the level of the knot. In fact, we would argue that it is above all in order to explore this transformative aspect of knotting that Lacan explores jouissance as an enigma which drills a hole in sense. It is obvious that such a project has many consequences for the way in which psychoanalysis tries to situate the real form the perspective of the outside-sense. But it is also from this perspective that the notion of the semblant assumes its full value.

Lacan's theory of the semblant clearly follows a certain dynamic, a logic of its own. In Seminar XVIII, we can witness the displacement of this concept in relation to the quilting point. With his elaboration of the notion of the semblant Lacan throws precisely the quilting function of the signifier into relief. And it is by redefining what is at stake in this function that Lacan comes to effect, by replacing the term 'fiction' with that of 'semblant' a singular devaluation, the downgrading of the term whose role is precisely to pin down the real to the symbolic.

The notion of the semblant, under the guise of the fiction, was initially introduced by Lacan into psychoanalysis as an instance designed to situate the real in the symbolic, (which is to say, to make the real obey the rules of the signifier), in his later teaching, the same instances that were previously considered to secure access to the real, (the phallus, the master signifier, the Name-of-the-Father, the Other, the object $a$ ), and were as such valorised, now, under a new light, appeared to be the very obstacle on the path to the real, and were consequently downgraded to the status of semblance. In fact, the substitution of the term 'fiction' by 'semblant', to the extent that it implies a certain downgrading of the instance desigated as semblant, involves at the same time a shift of paradigms.

In this regard, it is perhaps not for no reason that Lacan, starting with Seminar XVIII, preferred the term 'semblant' to that of 'fiction'. However, this final choice cannot be justified by saying that the semblant, as a concept, is broader and can include the fiction, neither is it enough to insist on a distinction between 
discursive and non-discursive semblants, semblants in nature, since Lacan is primarily interested in discursive semblants. On the contrary, what justifies the substitution is Lacan's re-examination of the nature of the semblant and the function attributed to it. Thus one could say that it is the inversion of perspective which makes Lacan downgrade the semblant. More particularly, an instance is denounced as semblant insofar as it responds to the function of the quilting point. What downgrades the semblant is precisely its function. From this inversed perspective which takes as its departure point the non-rapport of the symbolic and the real, all these instances of the quilting point are seen now as being but a mere make-believe, a cover-up.

Indeed, the semblant is essentially a make-believe: by pinning down the imaginary, the signifier which operates the quilting makes us believe that it is the thing itself. In other words, the semblant is a symbolic instance which, by operating the quilting, makes us believe that it is the other of the symbolic, namely the real. This is why, for Lacan, the father is by definition a semblance. The father namely only exists in the form of the signifier and it exists so long as this signifier, the Name-of-the-Father, produces certain effects. The phallus, from this view, is also seen as a semblant since, strictly speaking, it is but a supporting evidence for the semblance of the father. And there is yet another, a third figure of the semblant, more delicate than the other two, the object $a$, a name invented by Lacan to designate the remainder of jouissance which is not converted into the signifier, which remains outside the signifier's operation of quilting. If the object $a$, from this perspective, is yet another name for the semblant, alongside the father and the phallus, this is because it is strategically positioned at a place where instead of the expected jouissance one only encounters its loss. The object $a$ is the semblant as this operator effecting the conversion of the loss of jouissance, its lack, into a surplus, a surplus which, curiously is not to be found on the side of the real jouissance, but on the side of the symbolic. Hence the equivalence, established by Lacan, between the jouissance under the guise of the plus-de-jouir, and the sens-joui [enjoy-meant], the only jouissance that a speaking being can attain is precisely a sens-joui.

In fact, we might say that with the quilting point thus exposed, the affinity of the semblant to the hole, the void, is also brought to light. From such a perspective, all these various names of the quilting point have something in common: their only function is to veil, to cover up, with their flimsy materiality, a hole, a void 
in the structure. Indeed, we would argue that there is a structural, constitutive relation between the semblant and the hole. The question of the semblant is essentially the question of the relation between void and veil. By following J.A. Miller, we could propose the following succinct definition of the semblant: the semblant is a mask of nothing. ${ }^{26}$ As a matter of fact, the semblant is only encountered there where something is expected one encounters a hole, a void, an emptiness, an absence. The function of the semblant is then no other than to cover up, by its very presence, the empty place of an instance which is constitutively lacking. But in so doing the semblant at the same time reveals that this instance ex-sists only through this empty place.

In this regard psychoanalysis seems to be inversing Leibniz's famous question: instead of asking why there is something rather than nothing, the question with which psychoanalysis is preoccupied is rather: why is only a void, absence, emptiness is encountered there where something is expected? All semblants deployed by Lacan (from the phallus to the Other and Woman) are as many deceitful answers to this question. Semblants, in the final period of Lacan's teaching, are therefore all the instances designed to veil, to mask the nothing. Thus, the phallus is an instance covering up the castration, the Name-of-the-Father can be considered to be a mask concealing the hole in the Other of language, and finally Woman is nothing but a veil to disguise that there is no such a thing as a sexual relation. The semblant can then be designed as an envelope of nothing, an envelope which conceals precisely that behind the semblant there is nothing but the void.

Thus, it is precisely in throwing into relief the dialectics of void and veil that the concept of the quilting point comes undone. This conveys a profound switch in the line of Lacan's elaboration of the relation between the symbolic and the real which implies a renouncement of any kind of quilting point. In fact, this question of the articulation between the symbolic and the real, while giving up the operation of quilting these two orders, is one which offers a guiding thread through Lacan's seminar D'un discourse qui ne serait pas du semblant. Indeed, we would argue that it is precisely in order to overcome the impasse left over at the end of his seminar on the four discourses in which the revolving circle of the

26 Jacques-Alain Miller, "Of Semblants in the Relation Between Sexes", in Psychoanalytical Notebooks, (3/1999), p.10. 
four discourses leads to a somewhat unexpected and certainly unwanted conclusion: if there is no discourse which is not of semblant, this only means that any attempt at converting the real into the signifier brings about the emergence of the semblant. By paraphrasing Miller, one could thus say: what is signifyerised is by the same token 'semblentified'.

Certainly, taking seriously the real as a compass for psychoanalysis entails at the same time pushing psychoanalysis itself to its limits: not only beyond the Name-of-the-Father, that semblant which, according to Freud, represents the unsurpassable horizon for psychoanalysis, but even further: beyond the Freudian unconscious itself. One is almost tempted to say that the price to be paid for the orientation of psychoanalysis towards the real is the downgrading of the concept of the unconscious. From the perspective of the real, as has been underlined by Jacques-Alain Miller, "the unconscious itself appears as a response made to the real, at the level of the semblant, a response to the hole in the real,[ due to the fact that there is no sexual relation] a response which has to do with the vain effort to make the absence of sexual programming signify at the level of the real". ${ }^{27}$ One of the unexpected, indeed, paradoxical, consequences of such a radical position regarding the real, was that this reference to the real appears as a problematic as well as a problematising reference in Lacan. At the end of his teaching, Lacan even suggests that the status of the real is that of the symptom, a deduction made from the unconscious, that is to say, that the notion of the real, in the last analysis, is nothing more than his invention. However, if the question of the real poses itself to Lacan so persistently in the final period of his teaching, this is precisely because the real proper to the analytic experience is now considered to be resisting signifierisation, i.e. its conversion into the symbolic.

This is why Lacan in the Liturattere, the published part of the Seminar XVIII, proposes as a possible solution for holding together that which does not hold together a new concept, that of the littoral. To propose the littoral as a solution consists in nothing other than to propose the void itself as the mediator, the "void-median", as Lacan calls it. The operation of the "void-median" or the littoral is the inverse of the quilting operation since, with the littoral, the void holds together by keeping the heterogeneous instances apart. “... between knowledge

${ }_{27}$ Jacques-Alain Miller, unpublished cours entitled L'exprérience du réel dans la cure analytique, lesson of the 25 November 1998. 
and jouissance, there is a littoral that only turns towards the literal on condition that this turn may be taken likewise at any instance." ${ }^{28}$ Littoral, by activating the void itself as a mediator is certainly a way of relating to jouissance which can do without the semblant. On the other hand, when Lacan posed a rhetorical question: "Is it possible for the littoral to constitute such a discourse that is characterised by not being issued form the semblant?"29 his answer is clearly no. The littoral can only testify to the fracture of which it is itself an effect. But it is unable to effect the cut. Only a discourse can produce a cut. One can see in what sense the theory of semblants constitutes a clearing gesture: indeed, it is only after bringing into question any instance of quilting that something as a littoral can be established, an empty plane in which something new can be inscribed. In the seminar D'un discourse qui ne serait pas du semblant Lacan seems to be still harbouring the hope of writing the formula of the sexual relation, a hope quenched with the seminar Encore. But just like the formula "there is no sexual relation" does not abolish the contingency of the encounter, the littoral proposes itself as a virgin canvas on which new combinations of knotting the real, the imaginary and the symbolic can be inscribed.

\section{References}

Freud, Sigmund, “Civilised” Sexual Morality and Modern Nervous Illness” (1908), trans. by. J. Strachey, SE, vol. 9

- Freud's letter to Fliess, dated 21 ${ }^{\text {st }}$ September 1897, Sigmund Freud Briefe 1873-1939, S. Fischer Verlag, Frankfurt am Main 1968

Lacan, Jacques, "The Function and Field of Speech and Language in Psychoanalysis" in Écrits, trans. B. Fink, W.W. Norton \& Company, New York/London 2006

- Television. A Challenge to the Psychoanalytic Establishment, trans. By D. Hollier, R. Krauss, and A. Michelson, W.W. Norton, New York, London, 1990

- The Seminar ofJacques Lacan, Book XX: Encore, or On Feminine Seuxality, The Limits of Love and Knowledge, trans. B. Fink, W.W. Norton \& Company, New York 1998

- The Seminar of Jacques Lacan. Book VII: The Ethics of Psychoanalysis, trans. D. Porter, Tavistock/Routledge, London 1992

- Le séminaire, livre XVI, D'un Autre à l'autre, Seuil, Paris, 2006

- Jacques Lacan, Le séminaire, livre XVIII : D’un discours qui ne serait pas du semblant, Seuil, Paris 2006

28 Jacques Lacan, Liturattere, in Autres écrits, Seuil, Paris 2001.

29 Ibid., p. 18. 
- The Seminar Jacques Lacan, book XVII: The Other Side of Psychoanalysis, trans. R. Grigg, W.W. Norton \& Company, New York/London 2007

- « Discours à l’Ecole Freudienne de Paris », in Autres écrits, Seuil, Paris 2001

- «L'Étourdit», in Autres écrits

- «Liturattere », in Autres écrits

Laurent, Éric, Miller, Jacques-Alain, « L’Autre qui n'existe pas et ses comités d'éthique », La Cause freudienne (35/1997)

Jacques-Alain Miller, “Of Semblants in the Relation Between Sexes”, in Psychoanalytical Notebooks, (3/1999)

- "Equivalence Between the Other and the Symptom”, Psychoanalytical Notebooks, $(12 / 2004)$

- “Le partenaire-symptôme," unpublished course of the 1997-98 